\title{
ANALISIS MODEL DISKREPANSI TENTANG PROGRAM PENDIDIKAN PEMBENTUKAN BINTARA POLRI DI SPN SINGARAJA TAHUN ANGGARAN 2017/2018
}

\author{
Oleh \\ Ida Ayu Km. Geriani ${ }^{1}$, Ni Ketut Suarni², Ni Made Sri Mertasari ${ }^{3}$ \\ Program Studi Penelitian dan Evaluasi Pendidikan, Program Pascasarjana \\ Universitas Pendidikan Ganesha \\ Singaraja, Indonesia \\ e-mail: dayu.geriani@yahoo.com, niketut.suarni@undiksha.ac.id, \\ srimertasari@yahoo.co.id

\begin{abstract}
Abstrak
Penelitian ini bertujuan untuk mendiskrepansi terkait Program Pendidikan Pembentukan Bintara Polri dan untuk mengetahui penyebab terjadinya diskrepansi. Penelitian ini termasuk penelitian evaluatif dengan model diskrepansi. Populasi penelitian ini adalah Kepala SPN dan Tenaga Pendidik di SPN Singaraja. Sampel penelitian ditentukan dengan teknik purposive random sampling. Data dikumpulkan dengan menggunakan lembar observasi dan wawancara sebagai tindak lanjut untuk mengetahui faktor penyebab terjadinya diskrepansi. Data dianalisis dengan menggunakan teknik analisis deskriptif kuantitatif. Hasil penelitian menunjukkan bahwa: (1) diskrepansi yang terjadi terkait variabel latar belakang Program Pendidikan Pembentukan Bintara Polri dengan sebesar 6,431 dengan kategori kecil; (2) diskrepansi yang terjadi terkait variabel masukan Program Pendidikan Pembentukan Bintara Polri sebesar 17,36 dengan kategori kecil; dan (3) diskrepansi yang terjadi terkait variabel pelaksanaan pembelajaran Program Pendidikan Pembentukan Bintara Polri sebesar 19,96 dengan kategori kecil; (4) diskrepansi yang terjadi terkait variabel lulusan dalam Program Pendidikan Pembentukan Bintara Polri sebesar 13,41, dengan kategori sangat kecil.
\end{abstract}

Kata kunci: diskrepansi, evaluasi, Program Pendidikan Pembentukan Bintara Polri

\begin{abstract}
This study aimed to determine the amount of discrepancies related to the implementation Education Program Formation of NCO officer and to determine the factors that hinder the occurrence of discrepancy. This research was an evaluative research with discrepancy model. The population of this research were headmaster and teachers at SPN Singaraja. The research sample were determined by using purposive random sampling technique. The data were collected by using learning observation sheet and interview as a follow-up to know the causative factor of discrepancy. The data of this research were analyzed by using quantitative descriptive analysis technique. The results showed that: (1) the discrepancy that occurred related to the context variables of Education Program Formation of NCO officer is 16,43 with small category; (2) the discrepancy that occurred related to the input variables of Education Program Formation of NCO officer is 17,36 with the small category; and (3) the discrepancy that occurred related to the process of Education Program Formation of NCO officer is 19,96 with a small category; (4) the discrepancy that occurred related to the output variables of learning Education Program Formation of NCO officer is 13,41 with a very small category.
\end{abstract}


Jurnal_ep, Vol. 9 No. 1, Maret 2019

Keywords : discrepancy, evaluation, scien Education Program Formation of NCO officer 


\section{PENDAHULUAN}

\begin{tabular}{ll}
\multicolumn{3}{c}{ Pendidikan merupakan suatu hal } \\
yang tidak dapat dipisahkan dari \\
kehidupan manusia. Pendidikan \\
mempunyai posisi penting dalam \\
pembangunan suatu bangsa. Pendidikan \\
merupakan proses memanusiakan
\end{tabular} manusia. Pendidikan dapat pula diartikan sebagai usaha sadar dan terencana untuk mewujudkan dan mengembangkan potensi sumber daya manusia untuk memiliki kekuatan spiritual, keagamaan, pengendalian diri, kepribadian, kecerdasan, akhlak mulia, serta ketrampilan yang diperlukan dirinya, masyarakat bangsa dan Negara. Seperti yang dijelaskan dalam Undang-Undang tentang fungsi pendidikan, bahwa:

Pendidikan nasional berfungsi mengembangkan kemampuan dan membentuk watak serta peradaban bangsa yang bermatabat dalam rangka mencerdaskan kehidupan bangsa, bertujuan untuk berkembangnya potensi peserta didik agar menjadi manusia yang beriman dan bertakwa kepada Tuhan Yang Maha Esa, beraklak mulia, sehat, berilmu, cakap, kreatif, mandiri dan menjadi warga negara yang demokratis serta tanggung jawab (Pasal 3 UU No. 20 Tahun 2003).

Pendidikan diarahkan untuk meningkatkan kualitas manusia Indonesia seutuhnya melalui olahhati, olahrasa, olahpikir, dan olahraga agar memiliki daya saing dalam menghadapi tantangan global. Sehubungan dengan upaya pemenuhan personel Polri, Kepolisian Republik Indnesia setiap tahun melaksanakan seleksi penerimaan untuk menjadi calon bintara Polri. Pada pelaksanaannya, Kapolri mendeligasikan kewenangan kepada Kapolda dan jajaran melalui seleksi penerimaan Bintara Polri yang dilaksanakan di Kepolisian Daerah. Hal ini dilaksanakan untuk memenuhi standar rasio jumlah personel Polri sesuai dengan DSP (Daftar Susunan Personel). Lembaga Pendidikan formal seperti SPN/Pusdik mengemban tugas penting untuk menyiapkan Sumber Daya Manusia (SDM) Polri yang berkualitas di masa depan.
Berdasarkan Peraturan Kapolri No 14 Tahun 2015 disebutkan bahwa Pendidikan Pembentukan Bintara Polri adalah pendidikan yang membentuk dan membekali peserta didik menjadi pegawai negeri pada Polri. Lembaga pendidikan dan pelatihan Polri merupakan salah satu organisasi Kepolisian Negara Republik Indonesia yang memiliki tugas pokok, fungsi dan peran yang sangat strategis untuk melakukan transfer karakter bangsa melalui pendidikan melalui pendidikan secara berkelanjutan.

Hal ini sejalan dengan kebijakan pemerintah $\mathrm{RI}$ yang baru untuk melakukan pembenahan karakter bangsa Indonesia melalui revolusi mental sehingga terjadi transformasi besar dalam kehidupan berbangsa dan bernegara, yang hasil dari proses transformasi inilah yang diharapkan dapat membangun karakter Polri yang kuat antara lain berpikiran maju, berpandangan modern, berprilaku baik, memiliki bu pekerti, dan kepribadian yang baik, memiliki mentalitas yang bermuara pada nilai-nilai Pancasila, dapat dipercaya, mandiri, kreatif, gotong royong dan saling menghargai serta berperan sebagai penggerak revolusi mental dan pelopor tertib sosial di ruang publik. Berdasarkan hal tersebut, menunjukkan kesatuan yang utuh sehingga memiliki potensi dan kemampuan yang memancarkan kewibawaan.

Dalam proses pendidikan dan pelatihan para siswa Bintara Polisi Baru diberikan tes yang berhubungan dengan materi dan pelatihan yang didapat di SPN, sehingga dari tes tersebut didapat nilainilai yang nantinya dipakai sebagai bahan evaluasi penentuan kelulusan bagi Bintara Polisi Baru. Nilai tersebut, akan dipergunakan sebagai dasar dalam proses kelulusan siswa Pendidikan Pembentukan Bintara Polri. Terdapat tiga aspek penilaian yang meliputi akademik, mental, dan kesamaptaan jasmani. Ketiga nilai aspek ini akan dilaporkan pada sidang dewan pimpinan SPN untuk dijadikan acuan dalam menentukan kelulusan siswa Pendidikan Pembentukan Bintara Polri.

Namun dalam melaksanakan fungsi dan tugasnya sebagai bintara Polri, masih ada beberapa oknum bintara Polri 
yang melaksanakan tugas dan fungsinya belum profesional. Hal tersebut menimbulkan kesan yang kurang baik di mata masyarakat. Berdasarkan hal tersebut, perlu adanya peningkatan dalam proses pendidikan calon bintara Polri agar nantinya menghasilkan keluaran atau lulusan bintara Polri yang kompeten dibidangnya. Kualitas lulusan siswa Pendidikan Pembentukan Bintara Polri ditentukan dari kemampuan tenaga pendidik dalam mendidik calon bintara Polri. Berdasarkan Perkap nomor 10 Tahun 2010 pasal 1 menyebutkan bahwa;Tenaga Pendidik yang selanjutnya disingkat Tenaga pendidik adalah seseorang yang berkualifikasi sebagai tenaga pendidik, pelatih, dosen, konselor, widyaiswara, instruktur,fasilitator, dan tutor. Tenaga Pendidik merupakan tenaga profesional yang melakukan tugas pokok dan fungsi guna meningkatkan pengetahuan, keterampilan, dan sikap peserta didik/siswa sebagai aset Polri masa depan, dalam rangka mendukung pembangunan nasional. Hal tersebut diperkuat dengan Perkap No 14 Tahun 2015 Ayat 32 yang menyatakan bahwa tenaga kependidikan adalah Pegawai negeri pada Polri yang bertugas melaksanakan administrasi, pengelolaan, pengembangan, pengawasan, dan evaluasi program serta pelayanan teknis untuk menunjang proses Pendidikan pada Satuan Pendidikan Polri.

Standar yang terkait erat dengan proses pendidikan pembentukan Bintara Polri tertuang dalam Perkap No 20 Tahun 2007 tentang Standar Komponen Pendidikan untuk Pendidikan Pembentukan dan Pendidikan Pengembangan di Lingkungan Lembaga Pendidikan dan Pelatihan Kepolisian Negara Republik Indonesia. Berdasarkan Perkap No 20 Tahun 2007, standar pendidikan meliputi perencanaan proses pembelajaran, pelaksanaan proses pembelajaran, dan penilaian proses pembelajaran untuk terlaksananya pembelajaran pembentukan Bintara Polri yang berkualitas agar lulusan memiliki kemampuan yang kompeten di bidangnya.

Berdasarkan Perkap No 20 Tahun 2007, prencanaan proses pembelajaran dirancang dalam bentuk silabus dan Desain Pembelajaran yang memuat mata pelajaran, materi pokok, indikator, waktu, pelaksanaan kegiatan, dan sarana dan prasarana. Perencanaan pembelajaran yang disusun secara terarah, runtut, dan terukur agar dapat menilai semua aspek perkembangan siswa.

Pelaksanaan proses pembelajaran merupakan implementasi dari Desain Pembelajaran yang terdiri dari kegiatan pendahuluan, kegiatan inti, dan penutup. Pembelajaran diselenggarakan secara interaktif, inspiratif, menyenangkan, menantang, memotivasi siswa untuk berpartisipasi aktif, memberikan ruang yang cukup bagi prakarsa, kreativitas,dan kemandirian sesuai dengan bakat, minat, dan perkembangan fisik serta psikologis siswa. Untuk tercapainya pembelajaran yang interaktif dibutuhkan perhatian penuh Tenaga Pendidik. Selain itu Tenaga Pendidik juga harus memiliki kemampuan dalam mengelola kegiatan belajar yang disesuaikan dengan karakteristik siswa.

Penilaian terhadap kegiatan hasil belajar siswa mencakup aspek afektif, kognitif, dan psikomotorik. Penilaian terhadap kegiatan dan kemajuan belajar siswa dilakukan dengan menggunakan pendekatan berbasis kelas yang terdiri dari ujian tertulis, produk, dan penampilan yang dilakukan secara berkala oleh pendidik. Penilaian terhadap hasil belajar siswa dilakukan secara menyeluruh dan berkesinambungan sesuai dengan karakteristik pendidikan Polri serta memperhatikan ketentuan penilaian yang berlaku.

Berdasarkan hasil analisa dan evaluasi Tenaga Pendidik tahun 2016 di lingkungan lemdik Polri SPN Singaraja diperoleh bahwa Kualitas kompetensi Tenaga Pendidik (Tenaga pendidik) Sekolah Polisi Negara/Pusdik dilingkungan Lembaga Pendidikan Polri masih belum memenuhi kreteria. Hal tersebut terlihat dari kurang beragamnya metode pembelajaran yang diterapkan oleh tenaga pendidik dalam membelajarkan calon bintara. Selain itu dari hasil observasi yang dilakukan ditemukan masalah yang dialami Tenaga Pendidik antara lain: 1) Tenaga Pendidik 
menyusun desain pemebelajaran masih berdasarkan contoh Desain Pembelajaran dari teman sejawat tanpa melihat atau menyesuaikan dengan Perkap yang mengatur, 2) sebagian besar pembelajaran dilakukan dengan metode ceramah, 3) penilaian dilakukan pada akhir pembelajaran saja dengan melakukan ujian akademik, 4) kurangnya pemanfaatan sarana dan prasana sekolah dalam pembelajaran.

Berdasarkan pemaparan tersebut, terlihat adanya kesenjangan antara kenyataan dengan yang diharapkan Kepolisian Republik Indonesia yang tertuang dalam Perkap No 20 Tahun 2007 tentang Standar Komponen Pendidikan untuk Pendidikan Pembentukan dan Pendidikan Pengembangan di Lingkungan Lembaga Pendidikan dan Pelatihan Kepolisian Negara Republik Indonesia. Oleh karena itu perlu dilaksanakan evaluasi terhadap kesenjangan

\section{METODE}

Penelitian ini dilaksanakan di SPN Singaraja tahun anggaran 2017/2018 dengan mengevaluasi pelaksanaan Program Pendidikan Pembentukan Bintara Polri. Penelitian ini menggunakan rancangan penelitian jenis evaluasi program. Model evaluasi diskrepansi adalah sebuah proses pengelolaan informasi yang menekankan pada pandangan adanya kesenjangan di dalam pelaksanaan program secara berlanjut. Pada penelitian ini akan dilakukan analisis kesenjangan (diskrepansi) antara Perkap No 20 Tahun 2007 tentang Standar Komponen Pendidikan untuk Pendidikan Pembentukan dan Pendidikan Pengembangan di Lingkungan Lembaga Pendidikan dan Pelatihan Kepolisian Negara Republik Indonesia. Dari hasil analisis tersebut selanjutnya dikaji kembali terkait faktor penyebab terjadinya kesenjangan pada Program Pendidikan Pembentukan Bintara Polri.

Populasi pada penelitian adalah Kepala Sekolah Polisi Negara Singaraja dan seluruh Tenaga pendidik di SPN Singaraja tahun anggaran 2017/2018. Jumlah tenaga pendidik fungsional di SPN Singaraja adalah 57 orang yang rata- pelaksanaan Program Pendidikan Pembentukan Bintara Polri yang dilaksanakan dengan standar program yang telah ditetapkan untuk mengetahui besarnya kesenjangan yang terjadi.

Berdasarkan uraian di atas, untuk mengetahui keefektifan pelaksanaan Program Pendidikan Pembentukan Bintara Polri maka peneliti tertarik untuk mengadakan penelitian tentang pelaksanaan program tersebut dengan judul:

"Analisis Model Diskrepansi Tentang Program Pendidikan Pembentukan Bintara Polri di SPN Singaraja Tahun Anggaran 2017/2018".

Adapun tujuan yang ingin dicapai dalam penelitian ini adalah penelitian ini adalah untuk mengetahui efektivitas pelaksanaan Program Pendidikan Pembentukan Bintara Polri di SPN Singaraja.

rata sudah teruji dan lulus serta memiliki sertifikasi uji kompetensi tenaga pendidik dari lembaga sertifikasi pendidikan Kepolisian Negara Republik Indonesia. Dalam penelitian ini, teknik yang digunakan adalah purposive random sampling. Purposive random sampling digunakan karena objek yang akan diteliti sudah ditentukan berdasarkan tujuan penelitian. Adapun tujuan dari penelitian ini adalah untuk mendapatkan data atau informasi yang akurat terkait Program Pendidikan Pembentukan Bintara Polri. Jadi, sampel yang akan dipilih berfokus pada orang-orang yang mempunyai pengetahuan dan pengalaman mengenai program yang akan dievaluasi yaitu Program Pendidikan Pembentukan Bintara Polri. Sehubungan dengan hal tersebut, maka yang akan menjadi sampel pada penelitian ini adalah tenaga pendidik di SPN yang mengajar tentang Program Pendidikan Pembentukan Bintara Polri. Adapun jumlah sampel adalah 15 orang tenaga pendidik di SPN Singaraja.

Variabel yang diukur dalam penelitian ini adalah Program Pendidikan Pembentukan Bintara Polri. Adapun variabel-variabel yang terlibat dalam 
penelitian evaluasi program ini adalah sebagai berikut: 1) variabel latar belakang 2) variabel masukan; dan 3) variabel pelaksanaan pembelajaran, dan 4) variabel lulusan. metode pengumpulan data yang digunakan adalah metode observasi dengan jenis observasi berstruktur, sebab dalam penelitian ini dilakukan penilaian terhadap siswa yang telah ditentukan indikator penilaiannya. Dalam penelitian ini data yang diperlukan adalah data tentang pelaksanaan Program Pendidikan Pembentukan Bintara Polri mulai dari perencanaan, pelaksanaan, serta penilaian proses pembelajaran pembentukan Bintara Polri. Untuk mengumpulkan data digunakan metode observasi dengan jenis observasi berstruktur. Untuk menilai aspek dalam pelaksanaan pembelajaran siswa, yang digunakan adalah rubrik dengan skala rating. Berdasarkan penilaian dengan menggunakan skala rating (skala berjenjang), setiap indikator yang akan diukur dibuatkan skala tertentu misalnya dari 1-5 yang setiap skala tersebut memiliki makna mulai dari kategori sangat baik, baik, cukup baik, kurang baik, dan tidak baik. Setiap kategori dalam rubrik memiliki deskripsi verbal yang diwakili. Bunyi deskripsi verbal harus sesuai dengan rubrik yang akan diukur. Penilaian tingkat capaian siswa dilakukan dengan menandai angka-angka.

Data hasil penelitian dianalisis secara deskriptif kuantitatif. Teknik analisis deskriptif dalam penelitian ini digunakan untuk mengetahui tinggi rendahnya kualitas dari kemampuan tenaga pendidik dan kesenjangan yang terjadi terkait Program Pendidikan Pembentukan Bintara Polri di SPN Singaraja. Untuk mengetahui tinggi rendahnya kualitas dari kemampuan tenaga pendidik dalam Program Pendidikan Pembentukan Bintara Polri yaitu dengan memberi skor dari 1 sampai 5 pada lembar observasi sesuai kinerja yang ditunjukkan oleh tenaga pendidik terkait Program Pendidikan Pembentukan Bintara Polri. Setelah mendapatkan skor kinerja tenaga pendidik, kemudian dikonversi ke dalam data persentil. Dilanjutkan dengan menghitung nilai ratarata dan terakhir dikonversikan kedalam tabel Penilaian Acuan Kriteria sebagai berikut

Tabel 1. Klasifikasi Kemampuan Guru

\begin{tabular}{|c|c|c|}
\hline No & $\begin{array}{c}\text { Kriteria Penguasaan } \\
(\%)\end{array}$ & Keterangan \\
\hline 1 & $90-100$ & Sangat Baik \\
\hline 2 & $80-89$ & Baik \\
\hline 3 & $65-79$ & Cukup Baik \\
\hline 4 & $40-64$ & Kurang Baik \\
\hline 5 & $0-39$ & Sangat Kurang Baik \\
\hline
\end{tabular}

(Sumber: Dantes, 2014:215) 
Selanjutnya, untuk mengetahui tingkat kesenjangan antara kemampuan guru yang terobservasi dianalisis dengan menggunakan analisis diskrepansi. Uji analisis diskrepansi bertujuan untuk mengetahui apakah terdapat perbedaan nyata (kesenjangan) antara standar acuan dengan pelaksanaan standar proses oleh tenaga pendidik pada satuan pendidikan. Sehingga, didapatkan skor kesenjangan (dalam persentil) kemudian dikonversikan ke dalam tabel Diskrepansi Penilaian Acuan Kriteria (D-PAK) yang merupakan adaptasi dari Penilaian Acuan Kriteria (PAK) yaitu sebagai berikut

Tabel 2. Acuan Kriteria Diskrepansi

\begin{tabular}{|l|l|}
\hline Besar Beda dengan Standar & Kategori Diskrepansi \\
\hline $25<($ besar beda $) \leq 0$ & Tidak Ada Kesenjangan $($ TS) \\
\hline $0<($ besar beda $) \leq 15$ & Sangat Kecil $($ SK $)$ \\
\hline $15<($ besar beda $) \leq 30$ & Kecil $($ K) \\
\hline $30<($ besar beda $) \leq 45$ & Cukup Besar $(\mathrm{CB})$ \\
\hline $45<($ besar beda $) \leq 60$ & Besar $(\mathrm{B})$ \\
\hline $60<($ besar beda $) \leq 75$ & Sangat Besar $(\mathrm{SB})$ \\
\hline
\end{tabular}

(Sumber: Dantes, 1983)

\section{HASIL DAN PEMBAHASAN}

Berdasarkan hasil analisis data diperoleh nilai rata-rata variabel latar belakang dalam Program Pendidikan Pembentukan Bintara Polri adalah 84,39 dengan kategori baik dan besarnya diskrepansi yang terjadi terkait variabel latarbelakang dalam Program Pendidikan Pembentukan Bintara Polri 15,61 dengan kategori diskrepansi kecil. Hasil analisis diskrepansi pada variabel latar belakang pada Program Pendidikan Pembentukan Bintara Polri disajikan pada tabel berikut.

Tabel 3. Rekapitulasi Hasil Analisis Diskrepansi terkait Variabel Latar Belakang Program Pendidikan Pembentukan Bintara Polri

\begin{tabular}{|l|c|c|c|c|}
\hline \multicolumn{1}{|c|}{ Dimensi } & $\begin{array}{c}\text { Profil Tempat } \\
\text { Belajar }\end{array}$ & $\begin{array}{c}\text { Kebutuhan yang } \\
\text { Akan Dicapai }\end{array}$ & Kebijakan Program & Total \\
\hline Standar & 100 & 100 & 100 & 100 \\
\hline $\begin{array}{l}\text { Capaian (dalam } \\
\text { Persentil) }\end{array}$ & 84,64 & 86,88 & 81,67 & 84,39 \\
\hline Besar Beda & 15,36 & 13,13 & 18,33 & 15,61 \\
\hline Kategori & $\mathrm{K}$ & $\mathrm{SK}$ & $\mathrm{K}$ & $\mathrm{K}$ \\
\hline
\end{tabular}

Data hasil penelitian menunjukkan bahwa terdapat diskrepansi dengan kategori kecil pada aspek profil tempat belajar dan kebijakanprogram. Sedangkan pada aspek kebutuhan yang akan dicapai terjadi diskrepansi dengan kategori sangat kecil. Ini karena lingkungan tempat belajar siswa belum sepenuhnya mendukung Program Pendidikan Pembentukan Bintara Polri. Hal tersebut karena letak SPN Singaraja yang dekat dengan fasilitas umum yang dalam hal ini adalah pasar Banyuasri yang terkadang menghambat proses pembelajaran jasmani Bintara. Pembelajaran pembentukan jasmani Bintara dilakukan degan melakukan kegiatan-kegiatan fisik ke luar SPN Singaraja, seperti lari, lintas medan, hiking, dan lain sebagainya. Kemacetan seringkali membuat jam pelajaran melebihi waktu yang ditentukan. Hal tersebut menyebabkan Bintara dalam mempersiapkan kegiatan/pembelajaran selanjutnya menjadi tergesa-gesa.

Kesenjangan juga terlihat pada dimensi perumusan visi dan misi sekolah. Terdapat tenaga pendidik yang belum memahami sepenuhnya mengenai visi 
dan misi SPN Singaraja. Kurangnya pemahaman terhadap visi dan misi sekolah membuat visi dan misi sekolah yang telah dirumuskan sulit untuk diwujudkan. Selain itu, pembelajaran yang diberikan kepada siswa kurang terarah terhadap visi dan misi yang telah dirumuskan. Hal tersebut karena kurangnya sosialisasi tentang pemahaman dari visi dan misi SPN yang dilakukan oleh Ka SPN Singaraja.

Kesenjangan juga terlihat pada dimensi kebijakan SPN yaitu pelaksanaan widya bara tangkas sebagai program SPN yang mendukung keprofesionalan Bintara Polri. Program sekolah perlu mendapat dukungan bukan hanya dari warga sekolah saja tetapi juga dari warga sekitar sekolah atau masyarakat. Program sekolah yang disusun belum banyak mendapatkan dukungan dari masyarakat sekitar. Hal ini disebabkan kurangnya sosialisasi kepada masyarakat mengenai program sekolah yang dijalankan. Kurangnya keterlibatan masyarakat menyebabkan kurangnya efektivitas variabel latar belakang dalam Program Pendidikan Pembentukan Bintara Polri.
Sehingga, dapat disimpulkan bahwa terdapat diskrepansi dengan kategori kecil terkait variabel latar belakang dalam Program Pendidikan Pembentukan Bintara Polri di SPN Singaraja. Oleh karena itu, pendidik diharapkan mampu, mengembangkan, kegiatan pembelajaran sesuai dengan visi dan misi yang telah dirumuskan serta kondisi dan situasi lingkungan setempat. Selain itu, tenaga pendidik hendaknya selalu berinovasi dan berkreasi di dalam penyusunan pembelajaran sehingga terjadi proses pembelajaran yang interaktif, inspiratif, menyenangkan, menantang, dan memotivasi.

Nilai rata-rata variabel masukan dalam Program Pendidikan Pembentukan Bintara Polri adalah 83,36 dengan kategori baik dan besarnya diskrepansi yang terjadi terkait variabel masukan pembelajaran pada Program Pendidikan Pembentukan Bintara Polri sebesar 16,64 dengan kategori diskrepansi kecil. Hasil analisis diskrepansi pada variabel masukan pada Program Pendidikan Pembentukan Bintara Polri disajikan pada tabel berikut.

Tabel 4. Rekapitulasi Hasil Analisis Diskrepansi terkait Variabel Masukan Program Pendidikan Pembentukan Bintara Polri

\begin{tabular}{|l|c|c|c|c|}
\hline Dimensi & $\begin{array}{c}\text { Latar } \\
\text { Belakang } \\
\text { Siswa }\end{array}$ & $\begin{array}{c}\text { Ketersediaan } \\
\text { Tenaga } \\
\text { Pendidik }\end{array}$ & $\begin{array}{c}\text { Kelengkapan } \\
\text { Sarana dan } \\
\text { Prasarana }\end{array}$ & Total \\
\hline Standar & 100 & 100 & 100 & 100 \\
\hline $\begin{array}{l}\text { Capaian (dalam } \\
\text { Persentil) }\end{array}$ & 85,42 & 84,17 & 80,49 & 83,36 \\
\hline Besar Beda & 14,58 & 15,83 & 19,51 & 16,64 \\
\hline Kategori & SK & $\mathrm{K}$ & $\mathrm{K}$ & $\mathrm{K}$ \\
\hline
\end{tabular}

Data hasil penelitian menunjukkan bahwa terdapat diskrepansi dengan kategori kecil pada aspek ketersediaantenaga pendidi dan kelengkapan sarana dan prasarana. Sedangkan pada aspek latar belakang siswa terjadi diskrepansi dengan kategori sangat kecil. Ini karena dalam penerimaan siswa baru, syarat utama yang harus dipenuhi dari calon peserta didik adalah tidak adanya cacat fisik dan mental. Hal tersebut telah ditentukan dalam standar acuan, yang menyatakan bahwa untuk menjadi seorang bintara harus sehat jasmani dan rohani agar nantinya dapat mengemban tugas secara profesional. Selain dari cacat fisik bawaan dari lahir, penerimaan peserta didik baru juga memperhitungkan cacat fisik yang terjadi karena suatu kecelakaan, misalnya bekas luka. Hal tersebut menyebabkan terjadinya diskrepansi dalam hal latar belakang peserta didik, karena tidak hanya cacat bawaan lahir yang diperhitungkan tetapi kesempurnaan dari seluruh segi fisik juga diperhatikan yang 
membuat tidak semua orang dapat menjadi seorang Bintara Polri.

Hal lain yang menyebabkan terjadinya kesenjangan dalam variabel masukan adalah kurangnya pemahaman tenaga pendidik mengenai Program Pendidikan Pembentukan Bintara Polri. Hal tersebut ditunjukkan dengan kegiatan pembelajaran yang disusun pendidik belum optimal dalam mengembangkan keprofesionalan sebagai Bintara Polri. Hal tersebut tidak sesuai dengan Perkap No. 20 Tahun 2007 yang menghendaki bahwa penyusunan proses pembelajaran berpusat pada peserta didik untuk mendorong motivasi, minat, kreativitas, kemandirian, dan semangat belajar peserta didik. Hal tersebut karena tidak semua pendidik mengikuti pembinaan dan pelatihan tenaga pendidik. Dalam pelatihan tenaga pendidik diberikan pemahaman mengenai kurikulum, pelatihan mengenai penyusunan perencanaan pembelajaran, proses pembelajaran, serta penilaian pembelajaran. Ketidak ikutsertaan tenaga pendidik dalam pelatihan menyebabkan pengorganisasian pengalaman belajar atau kegiatan belajar yang dirancang belum sepenuhnya dapat berpusat pada siswa. Selain itu dari dimensi tenaga pendidik kesenjangan juga terlihat pada kualifikasi tenaga pendidik. Tidak semua kualifikasi pendidik Strata 1 (S1). Hal tersebut juga menyebabkan pembelajaran kurang maksimal. Oleh karena itu, untuk menyetarakan kemampuan tenaga pendidik, hendaknya dilakukan pelatihanpelatihan agar memberikan penyegaran dalam hal proses pembelajaran sehingga tenaga pendidik dapat berinovasi dalam mengembangkan proses pembelajaran.
Kesenjangan juga terlihat pada dimensi sarana dan prasarana pembelajaran. Terdapat pembelajaran yang tidak dapat difasilitasi untuk dilakukan di SPN, misalnya pelatihan renang untuk mengasah ketangkasan jasmani siswa. Kegiatan tersebut dilakukan di luar SPN dengan menyewa tempat yang dapat memfasilitasi kegiatan tersebut. Hal tersebut menyebabkan waktu pembelajaran menjadi tidak efektif. Waktu pembelajaran tidak sepenuhnya digunakan untuk kegiatan pembelajaran tapi juga dipotong untuk menuju ke lokasi pelatihan.

Sehingga, dapat disimpulkan bahwa terdapat diskrepansi dengan kategori kecil terkait variabel masukan dalam Program Pendidikan Pembentukan Bintara Polri di SPN Singaraja. Oleh karena itu, pendidik hendaknya selalu adaftif terhadap perubahan yang ada dan meningkatkan kemampuannya dalam mengimplementasikan pembelajaran, baik melalui kegiatan pelatihan, maupun dengan memanfaatkan teknologi informasi dan lebih sering aktif bertanya jika ada yang belum diketahui.

Nilai rata-rata variabel Pelaksanaan Pembelajaran pada Program Pendidikan Pembentukan Bintara Polri adalah 83,36 dengan kategori baik dan besarnya diskrepansi yang terjadi terkait variabel pelaksanaan pembelajaran pada Program Pendidikan Pembentukan Bintara Polri sebesar 20,78 dengan kategori diskrepansi kecil. Hasil analisis diskrepansi pada variabel pelaksanaan pembelajaran pada Program Pendidikan Pembentukan Bintara Polri disajikan pada tabel berikut.

Tabel 5. Rekapitulasi Hasil Analisis Diskrepansi terkait Variabel Pelaksanaan Program Pendidikan Pembentukan Bintara Polri

\begin{tabular}{|l|c|c|c|c|}
\hline Dimensi & $\begin{array}{c}\text { Pelaksanaan } \\
\text { Pembelajaran }\end{array}$ & $\begin{array}{c}\text { Pemanfaatan sarana } \\
\text { dan Prasarana }\end{array}$ & $\begin{array}{c}\text { Kunjungan Kepala } \\
\text { SPN }\end{array}$ & Total \\
\hline Standar & 100 & 100 & 100 & 100 \\
\hline $\begin{array}{l}\text { Capaian (dalam } \\
\text { Persentil) }\end{array}$ & 80,89 & 77,50 & 76,00 & 79,22 \\
\hline Besar Beda & 19,11 & 22,50 & 24,00 & 20,78 \\
\hline Kategori & $\mathrm{K}$ & $\mathrm{K}$ & $\mathrm{K}$ & $\mathrm{K}$ \\
\hline
\end{tabular}


Data hasil penelitian menunjukkan bahwa terdapat diskrepansi dengan kategori kecil pada seluruh aspek dalam variabel pelaksanaan pembelajaran. Ini karena masih terdapat pendidik yang jarang melakukan kegiatan apersepsi yaitu menyampaikan keterkaitan antara pembelajaran sebelumnya dengan materi yang akan dipelajari (pembelajaran bermakna), pendidik tidak menyampaikan tujuan pembelajaran dan hal-hal yang akan diukur dalam penilaian proses dan hasil belajar.

Kesenjangan juga terlihat pada dimensi kegiatan inti yang dilaksanakan oleh pendidik dalam proses pembelajaran. Ini berarti bahwa guru belum mampu mengimplementasikan pembelajaran yang berpusat pada siswa sehingga proses pembelajaran terkesan masih didominasi oleh tenaga pendidik. Selain itu, suasana belajar yang tercipta belum mendukung siswa untuk aktif, guru masih sering menggunakan metode pembelajaran konvensional seperti ceramah dan tidak semua pendidik menyiapkan media pembelajaran yang dapat mendorong siswa untuk aktif dalam proses pembelajaran. Kegiatan diskusi tetap terjadi akan tetapi hanya dilakukan oleh sebagian siswa saja sedangkan yang lainnya menunggu hasil diskusi, sehingga kegiatan bertukar informasi menjadi kurang intensif.

Kesenjangan lainnya juga terdapat pada dimensi kegiatan penutup yang dilaksanakan oleh pendidik dalam proses pembelajaran. Hal ini disebabkan karena pendidik tidak melaksanakan tindak lanjut dengan memberikan arahan, kegiatan, tugas sebagai remidi atau pengayaan dikarenakan terbatasnya waktu, dan tidak ada kegiatan tindak lanjut seperti penilaian kelompok serta tidak ada penjelasan mengenai materi yang akan dipelajari pada pertemuan selanjutnya.
Kesenjangan juga terlihat pada dimensi pemanfaatan sarana dan prasarana pembelajaran. Pendidik mengalami kesulitan untuk membuat media pembelajaran karena kurangnya kreativitas pendidik dan terbatasnya alat atau bahan untuk membuat media, sehingga pendidik tidak dapat menyusun media yang akan digunakan dalam proses pembelajaran yang sesuai dengan tuntutan materi.

Pada dimensi pengawasan pembelajaran yang dilakukan oleh Kepala SPN terdapat kesenjangan dengan kategori sangat kecil. Pengawasan pembelajaran terhadap pelaksanaan dan hasil program sekolah dilaksanakan secara berkesinambungan. Namun kesenjangan terlihat dari tim pengawas yang mendampingi Ka SPN. Terdapat tim pengawas yang memiliki kualifikasi pendidikan di bawah tenaga pendidik yang dinilai. Hal tersebut menyebabkan kemungkinan adanya penilaian terhadap tenaga pendidik yang tidak sesuai dengan kemampuan yang dimilikinya. Oleh karena itu, tim pengawas yang mendampingi $\mathrm{Ka}$ SPN dalam melakukan monitoring hendaknya memiliki kualifikasi pendidikan yang lebih tinggi dari tenaga pendidik yang dinilai atau minimal memiliki kuakifikasi yang sama dengan tenaga pendidik yang dinilai agar hasil yang didapatkan memang mencerminkan kemampuan tenaga pendidik yang dinilai.

Nilai rata-rata variabel lulusan pada Program Pendidikan Pembentukan Bintara Polri adalah 87,11 dengan kategori baik dan besarnya diskrepansi yang terjadi terkait variabel pelaksanaan pembelajaran pada Program Pendidikan Pembentukan Bintara Polri sebesar 12,89 dengan kategori diskrepansi sangat kecil. Hasil analisis diskrepansi pada variabel lulusan pada Program Pendidikan Pembentukan Bintara Polri disajikan pada tabel berikut. 
Tabel 6. Rekapitulasi Hasil Analisis Diskrepansi terkait Variabel Lulusan Program Pendidikan Pembentukan Bintara Polri

\begin{tabular}{|l|c|c|c|}
\hline \multicolumn{1}{|c|}{ Dimensi } & $\begin{array}{c}\text { Kompetensi yang Dicapai } \\
\text { Siswa }\end{array}$ & $\begin{array}{c}\text { Tingkat Lulusan } \\
\text { Siswa }\end{array}$ & Total \\
\hline Standar & 100 & 100 & 100 \\
\hline $\begin{array}{l}\text { Capaian (dalam } \\
\text { Persenti) }\end{array}$ & 83,39 & 90,83 & 87,11 \\
\hline Besar Beda & 16,61 & 9,17 & 12,89 \\
\hline Kategori & K & SK & SK \\
\hline
\end{tabular}

Data hasil penelitian menunjukkan bahwa terdapat diskrepansi dengan kategori sangat kecil pada variabel tingkat lulusan siswa sedangkan kategori variabel kompetensi yang dicapai siswa adalah kecil. Ini karena tidak terdapat peserta didik yang gagal dalam mengikuti ujian sekolah terkoordinasi. Pada dimensi ini kesenjangan terjadi karena terdapat beberapa siswa yang lulus hanya mencapai pada standar nilai kelulusan minimal yang ditentukan oleh pemerintah.

Kesenjangan juga aspek lulusan terlihat pada dimensi ketercapaian kompetensi pengetahuan, sikap dan keterampilan oleh peserta didik. Perkembangan kemampuan siswa selama mengikuti Program Pendidikan Pembentukan Bintara Polri belum dapat dipastikan sejauh mana peningkatannya oleh guru bersangkutan. Hal tersebut dikarenakan dalam menilai kemampuan siswa guru hanya menggunakan penilaian tes. Penilaian pembelajaran yang diisyaratkan Perkap No. 20 Tahun 2007 menggunakan penilaian autentik yang menilai aspek pengetahuan, sikap dan keterampilan. Penilaian yang dilakukan oleh guru lebih cenderung mengacu pada hasil akhir saja. Misalnya menemukan kesimpulan dari hasil kegiatan belajar. Pemberian pengujian semacam itu hanya akan menilai satu aspek (yaitu kognitif), sedangkan aspek afektif dan psikomotor tidak maksimal. Selain itu, sebagian besar penilaian hanya dilaksanakan oleh pendidik dengan kata lain kurang melibatkan siswa dalam melaksanakan penilaian, ketika menunjukkan hasil penilaian, tenaga pendidik hanya memberikan umpan balik terhadap hasil penilaian.
Ini berarti bahwa Tenaga pendidik belum maksimal melaksanakan tugasnya khususnya dalam melakukan penilaian pembelajaran. Dengan kata lain kenyataan dilapangan belum sesuai dengan Perkap No. 20 Tahun 2007.

Jadi, dapat disimpulkan bahwa terdapat diskrepansi dengan kategori sanat kecil terkait variabel lulusan dalam Program Pendidikan Pembentukan Bintara Polri. Oleh karena itu, pendidik hendaknya lebih sering mengikuti kegiatan pelatihan dalam mengimplementasikan asesmen autentik, baik melalui kegiatan pelatihan maupun dengan memanfaatkan teknologi informasi, dan lebih sering aktif bertanya jika ada yang belum diketahui tentang asesmen autentik. Selain itu, pendidik harus mampu mengembangkan penilaian autentik yang berkelanjutan (continuous authentic assessment) yang menjamin pencapaian dan penguasaan kompetensi.

Berdasarkan pemaparan di atas terkait variabel latar belakang, masukan, proses dan lulusan dapat disimpulkan bahwa pendidik hanya berkonsentrasi pada cara mereka dalam menyusun proses pembelajaran. Dengan kata lain, pendidik lebih siap untuk merencanakan proses pembelajaran dibandingkan dengan melaksanakan pembelajaran dan melaksanakan penilaian autentik.

\section{PENUTUP}

Berdasarkan hasil penelitian dan pembahasan secara mendalam, diperoleh bahwa besarnya diskrepansi yang terjadi terkait variabel latar belakang proses Program Pendidikan Pembentukan Bintara Polri di SPN Singaraja sebesar 16,43. Hal ini menunjukkan bahwa terdapat diskrepansi pada variabel latar belakang 
proses pembelajaran dengan kategori kecil. Besarnya diskrepansi yang terjadi terkait variabel masukan Program Pendidikan Pembentukan Bintara Polri di SPN Singaraja sebesar 17,36. Hal ini menunjukkan bahwa terdapat diskrepansi pada variabel masukan proses pembelajaran dengan kategori kecil. Besarnya diskrepansi yang terjadi terkait variabel pelaksanaan pembelajaran dalam Program Pendidikan Pembentukan Bintara Polri di SPN Singaraja sebesar 19,96. Hal ini menunjukkan bahwa terdapat diskrepansi pada pelaksanaan pembelajaran dengan kategori kecil. Besarnya diskrepansi yang terjadi terkait variabel lulusan dalam Program Pendidikan Pembentukan Bintara Polri di SPN Singaraja sebesar 13,41. Hal ini menunjukkan bahwa terdapat diskrepansi pada variabel lulusan dalam pembelajaran dengan kategori sangat kecil.

$\begin{array}{ccc}\text { Penyebab terjadinya } & \text { diskrepansi } \\ \text { tentang Program } & \text { Pendidikan }\end{array}$ Pembentukan Bintara Polri di SPN Singaraja yaitu Gadik kesulitan dalam menentukan media pembelajaran yang tepat, terdapat kegiatan pembelajaran yang belum sepenuhnya terfasilitasi di SPN Singraja seperti Kolam Renang, dimana ketika ada pelajaran renang SPN Singaraja harus menyewa sehingga membutuhkan waktu yang cukup lama untuk perjalanan keluar, disampimg itu belum semua Gadik mengikuti pembinaan dan pelatihan tentang professional seorang Gadik dan sebagian Gadik masih ditemukan belum sepenuhnya dapat melakukan penilaian secara langsung ketika proses pembelajaran sedang berlangsung.

\section{DAFTAR RUJUKAN}

Austriani, Ni Luh Putu Vina. 2015. Penerimaan Sumber Daya Manusia Brigadir Polri dalam Perspektif Governance (Studi Penerimaan Sumber Daya Manusia Kepolisian Daerah Bali Tahun Anggaran 2015). Skripsi (tidak diterbitkan). Fakultas IImu Sosial dan IImu Politik, Universitas Udayana.
Dantes, Nyoman. 2014. Landasan Pendidikan Tinjauan Dari Dimensi Makropedagogis. Yogyakarta: Graha IImu.

Keputusan Kepala Lembaga Pendidikan Polri Nomor: Kep/ 739/2013 September 2013 tentang Standar Pendidikan Polri. Jakarta.

Koyan, I. W. 2011a. Asesmen dalam Pendidikan. Singaraja: Universitas Pendidikan Ganesha Press.

Koyan, I. W. 2012. Statistik Pendidikan Teknik Analisis Data Kuantitatif. Singaraja: Universitas Pendidikan Ganesha Press.

Marhaeni, A. A. I. N. 2007. Evaluasi Program Pendidikan. Singaraja: Program Pascasarjana Undiksha.

Peraturan Kepala Lembaga Pendidikan Dan Pelatihan Kepolisian Negara Republik Indonesia Nomor 2 Tahun 2017 Tentang Standar Penilaian Pendidikan Kepolisian Negara Republik Indonesia.Jakarta.

Peraturan Kapolri Nomor 10 Tahun 2010 TentangTenaga Pendidik di Kepolisian Negara Republik Indonesia. Jakarta.

Peraturan Kapolri No 14 Tahun 2015 tentang Sistem Pendidikan Kepolisian Negara Republik Indonesia. Jakarta.

Peraturan Kapolri No 20 Tahun 2007 tentang Standar Komponen Pendidikan untuk Pendidikan Pembentukan dan Pendidikan Pengembangan di Lingkungan Lembaga Pendidikan dan Pelatihan Kepolisian Negara Republik Indonesia. Jakarta.

Perpres Nomor 2 tahun 2015 Tentang Rencana Pembangunan Jangka Menengah Nasional Tahun 20152019. Jakarta. 
Suharsimi, A. \& C. S. A. Jabar. 2010. Evaluasi Program Pendidikan. Jakarta: Bumi Aksara.

Tim Pokja Lemdiklat Polri. 2017. Revolusi Mental. Jakarta: Bagian Kurikulum Bahan Ajar Pendidikan Pembentukan Biro Kurikulum Lembaga Pendidikan dan Pelatihan Polri.

UU No. 3 Tahun 2002 Tentang Pertahanan Negara. Jakarta.

Undang-Undang Republik Indonesia Nomor 20 Tahun 2003 Tentang Sistem Pendidikan Nasional. Jakarta.

Wirawan. 2011. Evaluasi Teori, Model, Standar, Aplikasi, dan Profesi. Jakarta: PT Raja Grafindo Persada. 